\title{
УДК 2964
}

DOI: $10.21779 / 2500-1930-2018-33-3-41-46$

\section{С.А. Нажмутдинова, Н.А. Абдуллаев}

\section{Логистика «Нового Дагестана»}

Дагестанский государственный университет; Россия, 367001, 2. Махачкала, ул. М. Гаджиева,43a; caida_n@mail.ru

В статье рассматриваются проблемы логистического комплекса Республики Дагестан. Актуальность темы обусловлена недостаточной практической и теоретической разработанностью логистических процессов в республике. Одной из важных проблем, о которой говорят много, но бессистемно, является логистика - организация хранения и перевозки товаров, как производящихся в Дагестане, так и поступающих извне. Необходимо учитывать, что Дагестан находится на перепутье маршрутов Север-Юг, Запад-Восток, и чтобы его территория могла использоваться для транзита товаров, необходимо развивать логистику.

В статье рассмотрены проблемы и перспективы логистики в сельском хозяйстве, промышленности, складском хозяйстве, взаимодействия таможни и логистики, развития логистических комплексов в Республике Дагестан.

В заключении сделан вывод, что проблемы организации логистических комплексов в РД являются приоритетными в развитии курса на «Новый Дагестан».

Ключевые слова: логистика, логистические комплексы, таможенно-логистические терминаль, Республика Дагестан.

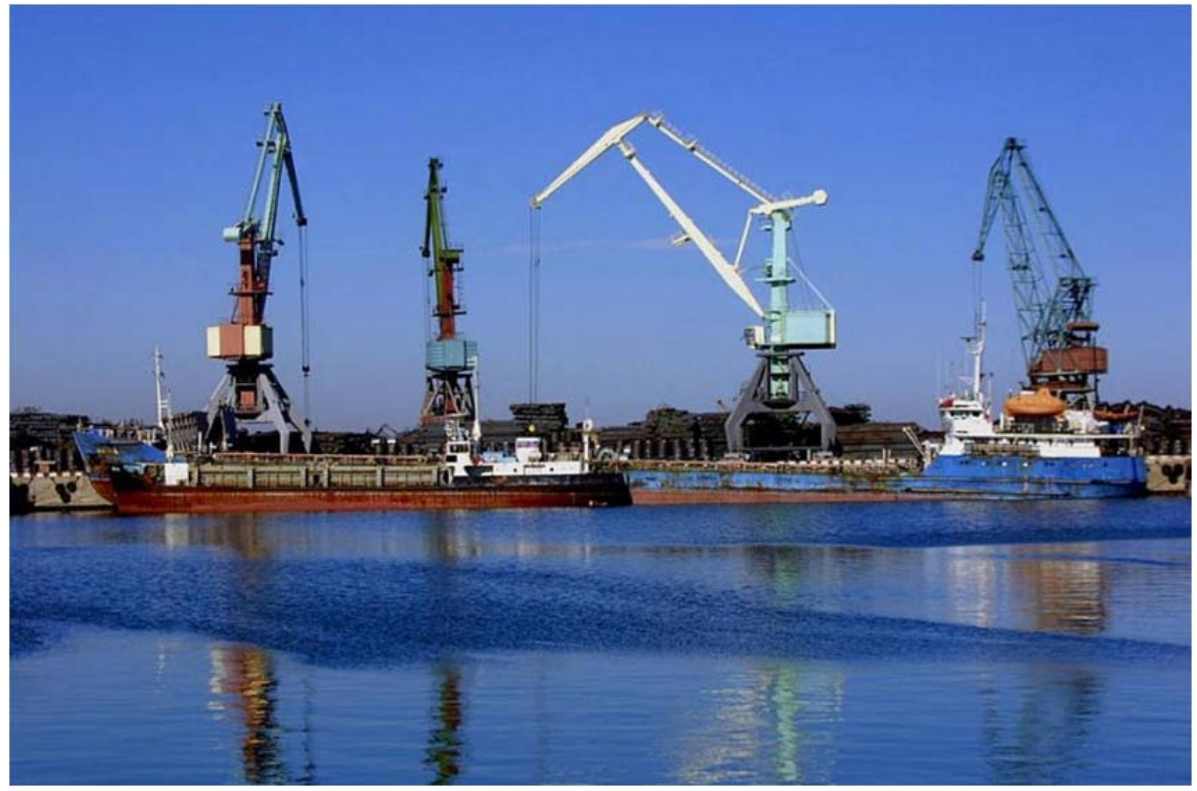

О Дагестане в настоящее время говорят часто и не самое хорошее. В последние годы республика меняется в лучшую сторону. Дагестан ежегодно увеличивает объемы производства во всех отраслях народного хозяйства и шаг за шагом приближается к тому, чтобы обходиться без дотаций из центра. 
Руководство республики взяло курс на «Новый Дагестан» - это своеобразная реинкарнация Дагестана прежних времен, но без недостатков и особенностей, характерных для эпохи Советского Союза. «Новый Дагестан» - первый в России республиканский бренд, под которым наш край хочет представить стране все лучшее, позитивное, что заслуживает внимания как в туристической сфере, так и в продукции агропромышленного комплекса и традиционных промыслов.

Одной из важных проблем, о которой много говорят, но которую не спешат решать, является логистика - организация хранения и перевозки товаров, как производящихся в республике, так и поступающих извне. Кроме того, надо учитывать, что Дагестан находится на перепутье маршрутов Север-Юг, Запад-Восток, и чтобы его территория могла использоваться для транзита товаров, надо сделать очень многое.

\section{Продукция сельского хозяйства}

Много лет в Дагестане расквартированы военные части. И все эти годы руководство республики предлагает обеспечить военных продуктами местного производства, начиная с овощей и фруктов, заканчивая мясом и хлебобулочными изделиями. Сегодня эта система несложная: объявляется тендер, и надо его выиграть, предложив армии условия, более выгодные, чем предложенные другими регионами и коммерческими структурами.

Дагестан может поставлять экологически чистые овощи и фрукты, причем в сезон их может быть очень много, как, например, в 2015 году: тогда в горах не знали, что делать с невиданным урожаем абрикосов, который не успевали перерабатывать на консервном заводе «Кикуни». Когда сезон завершается - заканчиваются овощи, ягоды и фрукты, которые производители из других регионов готовы поставлять сюда круглый год. Главная проблема кроется в том, что в Дагестане урожай, в конце концов, портится и выбрасывается.

В связи с этим возникает проблема логистики. Логистика - это процесс планирования, управления и контроля эффективного потока запасов сырья, материалов, незавершенного производства, готовой продукции, услуг и сопутствующей информации от места возникновения этого потока до места его потребления для целей полного удовлетворения запросов потребителей.

Нужно организовать склады для хранения овощей и фруктов на длительный срок с глубокой заморозкой, с использованием современных технологий, чтобы овощи и фрукты сохраняли свои вкусовые, питательные и полезные качества. Необходимо строить цеха для переработки фруктов и ягод в компоты, соки, нектары; мяса - в колбасы и полуфабрикаты. Та же проблема в рыбоводстве, разведении скота, производстве шерсти, молока и молочных продуктов.

Программа импортозамещения и приоритетный проект развития Республики Дагестан «Эффективный аграрно-промышленный комплекс» нацелены на рост производства продукции сельского хозяйства как через осуществление инвестиционных проектов и создание новых крупных предприятий агропрома, так и через развитие фермерских хозяйств. Необходимо развитие агрологистики. И крупным предприятиям, и небольшим фермерским хозяйствам будет удобно сдавать свою продукцию на склады, расположенные близоко от местонахождения сельскохозяйственного производства.

\section{Склады для хранения продуктов и промышленных изделий}

Примером развития логистики в РД является ООО «Агрико СК», которое приобрело земельный участок в Карабудахкентском районе общей площадью 100 га, где 
осуществляется инвестиционный проект «Строительство комплексного логистического центра», предусматривающий хранение, обработку, фасовку плодоовощной продукции, переработку мяса, возделывание и переработку риса, транспортную логистику.

Существующие в Дагестане хранилища с холодильным оборудованием рассчитаны примерно на 11 тыс. тонн. В Дагестане отсутствуют современные хранилища овощей, слабо развита система предпродажной подготовки, упаковки и фасовки. Это лишает возможности откладывать для хранения востребованную на рынках страны экологически чистую дагестанскую продукцию. Хранение овощей в неприспособленных овощехранилищах приводит к потере до 35 \% урожая. В связи с изложенным реализуется ведомственная целевая программа «Развитие логистических (оптово-распределительных) центров для хранения, предпродажной подготовки и реализации овощей, фруктов и картофеля в Республике Дагестан на 2015-2020 годы».

Одним логистическим проектом ООО «Агрико СК» дело не закончится. Нужно строить склады, ангары и цеха для переработки сельскохозяйственной продукции в тех местах, где имеются большие производственные мощности.

Для ОАО «Каспийский завод листового стекла» приоритетным рынком сбыта является домашний регион - Дагестан, Северный Кавказ, Юг России. Однако его интересуют и соседние страны, такие, как Армения, Грузия, Иран, Азербайджан, Восточная Украина, Западный Казахстан, Туркмения. Транспортная логистика именно в этом направлении остается экономически рентабельной. И естественно, на территории Дагестана необходимо строительство нескольких складов для готовой продукции.

\section{Логистика и таможня}

В Южном Дагестане организовано строительство таможенно-логистического терминала «Виадук». Благодаря новой площадке снизились транспортные потоки в Дербенте. На ней оперативно производится таможенное оформление практически всех автомашин, перевозящих скоропортящуюся сельскохозяйственную продукцию.

Цель таможни - своевременный осмотр и таможенное оформление ввозимых и вывозимых товаров. Необходима большая оперативность в работе таможни. И таможенно-логистический терминал «Виадук» значительно увеличил грузопоток, сэкономил время для многих водителей, пересекающих границу между Азербайджаном и Дагестаном. Идет реконструкция пункта пропуска Тагиркент-Казмаляр, строятся пешеходный переход на посту Яраг-Казмаляр, новый мост через реку Самур. На время строительства старый мост будет сохранен. Без этого просто невозможно сохранить оборот грузового транспорта между Россией, Азербайджаном и Ираном.

В рамках реализации программы «Север-Юг» завершается строительство железной дороги, которая свяжет Азербайджан с Ираном. Через республику пройдет один из самых удобных маршрутов, связывающих страны Ближнего Востока с Россией и Европой. Грузопоток через Дагестан вырастет, что принесет и рост таможенных платежей.

\section{Куда ведут дороги?}

Дагестан, будучи частью России, географически выгодно расположен и служит "мостом", связывающим Азию с Европой, являясь важным звеном международных транспортных сообщений между Севером и Югом, Западом и Востоком. Махачкалинский морской торговый порт считается единственным незамерзающим портом на Каспии и находится в выгодном географическом положении в зоне международных транспортных направлений. Кроме того, республика располагает международным аэропор- 
том, развитой сетью автомобильных дорог. Следовательно, здесь проходят важнейшие железнодорожные и автомобильные, воздушные, морские и трубопроводные магистрали федерального значения.

Занимая геостратегическое положение, Дагестан имеет прямой выход к морю. По суше и по морю он граничит со странами ближнего и дальнего зарубежья - Азербайджаном, Грузией, Казахстаном, Туркменистаном, Ираном. Развитие транспортной инфраструктуры имеет большое значение для экономики не только Дагестана, но и всей страны, так как обеспечивает им роль главных участников процесса транспортировки каспийской нефти и перевозки продукции, производящейся в Казахстане, Турции, Индии, Иране и других странах Юго-Восточной Азии.

Кроме того, уменьшатся сроки транспортировки грузов по направлению СеверЮг с 45 до 21 дня по существующим сейчас маршрутам через Индийский океан, Средиземное и Балтийское моря. Предполагается, что не менее чем на 20 \% сократятся затраты грузоотправителей на транспортировку и погрузочно-разгрузочные работы, будут в полной мере использоваться имеющиеся мощности трубопроводной сети, железнодорожного и морского транспорта страны.

Дагестан становится транспортным коридором для Северного Кавказа, всего Юга России. В данном направлении предстоит существенная работа. В этой связи нам нужно строить дороги быстро и без лишних затрат. Заложен новый мостовой переход из России в Азербайджан, который в ближайшее время возведут через реку Самур.

Как обещают власти, от границы Азербайджана должна выйти международная четырёхполосная трасса. Республика связывает с ней большие надежды на развитие экономики Дагестана.

Минтранспорта России берёт под контроль не только строительство этого моста, но и всю дальнейшую работу, связанную с ним.

Мост и международная трасса являются важным элементом стратегического проекта Минкавказа России - создания Каспийского транспортно-логистического комплекса. И здесь интересы не только республики, но и всей страны.

Это не просто мост между районами Азербайджана и России, это важнейшее звено международного транспортного коридора евразийского значения, поскольку именно через Дагестан и Азербайджан проходит транспортный коридор Север - Юг, который год от года показывает растущие результаты грузопотока и пассажирского движения.

Дагестан к моменту окончания строительства международной трассы, в силу географических (и политических) причин, возможно, останется только транзитной территорией. А Чечня, куда эта трасса, несомненно, свернёт, - значимым логистическим узлом, через который будут идти транспортные потоки в СКФО и далее. Дагестан тоже может стать серьёзным хабом, распределяя транспортные потоки на СКФО, ЮФО и Казахстан. Но об этом говорить пока рано.

Для организации транспортных потоков с грузами в Дагестан и из Дагестана необходимы современные освещенные автомобильные дороги. Идет реконструкция трассы «М-29» «Краснодар-Баку» на территории Дагестана.

Для улучшения торгово-экономических отношений с Грузией в планах строительство Аваро-Кахетинской дороги, которая свяжет с соседней страной приграничные районы Дагестана. Это даст и новые рабочие места, и дополнительные доходы от таможенного оформления товаров из Грузии, и возможность поездок дагестанцев в Грузию и наоборот. Нужны удобные современные дороги, связывающие Дагестан и соседние регионы - Ставропольский край и Республику Калмыкия. Это увеличит пассажирои грузопоток. 
Логистика - важная часть экономики любого региона. Отсутствие железнодорожного сообщения с европейской частью России во время чеченских войн сильно подкосило экономику Дагестана. И только строительство участка железной дороги «КизлярКазмаляр» в свое время дало возможность ездить и безопасно перевозить грузы в другие регионы страны.

В логистике Дагестана задач немало, но они решаются. Современные инновационные подходы к решению проблем республики - это очередной шаг к созданию и развитию «Нового Дагестана».

\section{Литература}

1. Величко А.П. Инновационное развитие в логистике и его связь с логистическим управлением и управлением логистикой // Маркетинг и менеджмент инноваций. - 2013. № 1. - C. 45-52. - Режим доступа: http://elibrary.ru/item.asp?id=22808704.

2. Рыжкков C.M. Развитие рынка плодоовощной продукции в Российской Федерации: монография. - М.: Дашков и $\mathrm{K}^{\circ}, 2015$.

3. Шкаберда В.Н. Построение системы сбалансированных показателей в логистике как основы контроллинга в логистике // Современные проблемы взаимодействия российского государства и общества. - 2016. - С. 74-76. - Режим доступа: https://elibrary.ru/item.asp?id=26085829.

4. Соколова М.Л., Чернов В.Г. Логистика транспортной инфраструктуры туризма (логистика туристических перевозок) // Вестник Владимирского государственного университета им. Александра Григорьевича и Николая Григорьевича Столетовых. Сер. Экономические науки. - 2014. - № 2(2). - С.95-104. - Режим доступа: http://elibrary.ru/contents.asp?id=34049961.

5. Степанов В.И., Рыкалина О.В., Шарова И.В. Предпринимательские решения в организации грузопотоков мегаполиса: монография. - М.: Дашков и К ${ }^{0}, 2016$.

6. Прокофьева T.A., Адамов Н.А. Стратегия развития логистической инфраструктуры в транспортном комплексе России: монография. - М.: ИД «Экономическая газета», ИТКОР, 2012.

7. Лазарев В.А., Кулькова И.А. Реверсивная логистика - логистика возвратных и обратных потоков // Управленец. - 2014. - № 5 (51). - С. 48-51. - Режим доступа: http://elibrary.ru/item.asp?id=22490109.

8. Барышникова Л.П., Попова Т.А. Логистика возвратных потоков - логистика нового поколения. Менеджер // Вестник Донецкого государственного университета управления. - 2016. - № 1. - С. 56-61. - Режим доступа: http://elibrary.ru/defaultx.asp.

9. Юсупова Б.М., Порсукова А. Маркетинговая логистика как результат интеграции логистики и маркетинга предприятия // Вопросы структуризации экономики. 2014. - Т. 2, № 3. - С. 19-20.

10. Рыжова O.A. Сетевая торговая логистика как самостоятельный раздел торговой логистики // Инновационная деятельность. - 2012. - № 19. - С. 78-82.

Поступила в редакцию 6 июня 2018 г. 
UDC 2964

DOI: $10.21779 / 2500-1930-2018-33-3-41-46$

\section{Logistics of «New Dagestan»}

\section{S.A. Nazhmutdinova, N.A. Abdullaev}

Dagestan State University; Russia, 367001, Makhachkala, M. Gadzhiev st., 43a; caida_n@mail.ru

The article deals with the analysis of a logistic complex in the Republic of Dagestan. The relevance of a subject is caused by inefficient practical and theoretical readiness of logistic processes in the republic. One of the important problems, much spoken about tends to have unsystematic character. Logistics - the organization of storage and transportation of the goods both made in Dagestan, and arriving from the outside sounds relevant. . It is necessary to consider that Dagestan routes the NorthSouth, the West-East at the crossroads and in order that his territory could be used for transit of goods, it is necessary to develop logistics.

The author dwells on the problems and prospects of logistics in agriculture, industry, warehouse economy, interactions of customs and logistics, the prospect of development of logistic complexes in the Republic of Dagestan.

In conclusion it is emphasized that the problems of the organization of logistic complexes in RD are of greatest priority in the development of a course to "New Dagestan".

Keywords: logistics, logistic complexes, customs logistic terminals, Republic of Dagestan.

Received 6 June, 2018 